\title{
Healthcare and unhealthy food for children under two years old: data from the National Health Survey, Brazil, 2013
}

\section{Dear editor,}

The study by Jaime PC et al. ${ }^{1}$ shows that there is an inequality on the issue of childcare access in Brazil, with only $28.7 \%$ of the children have their first medical appointment until the seventh day of life. There also were researches on unhealthy eating behaviors at childhood, with a high rate on the consumption of soft drinks, cookies, crackers, or cakes. Thus, it is clear when speaking about child healthcare, there is a national level problem and efforts should not be measured to generate methods and regulations, as well as guidelines of intervention so that this reality is taken into another direction.

It is known that in Brazil, there are still many challenges to overcome in order to qualify child health. 1 This can be exemplified by the low frequency of the newborn's first consultation in his/her first week of life, which can be expressed by the insufficient link of the maternities with primary care, and the timely access to the health network is not effective. ${ }^{1}$ In a study ${ }^{2}$ on child healthcare in Russia, they have put a pillar, the "neighborhood principle," at a polyclinic which allows excellent communication between health professionals and the child's family. ${ }^{2}$

A study conducted in Mexico in 2006 reports that infant feeding practices, which include breastfeeding and the introduction of complementary food, are determinants for the children's health, growth and development. ${ }^{3}$ However, in this study, 1 unhealthy foods, such as soft drinks and cookies, were consumed by children under two years of age. 1 This ultimately compromises the protection that breastfeeding and healthy eating offer gastroin- testinal and respiratory infections, immune functions, and can even cause retardation in a child's development. 3

Based on the studies mentioned above, this concludes that the rate of introducing some unhealthy food to children under two years of age has been increasing over the past years, increasing the chances of chronic comorbidities, such as diabetes, to appear more and more. It is necessary, then, to elaborate better proposals of intervention in the consultations with these children's mothers, aiming for healthier food. Along with this, primary care has an enormous responsibility for the children's first tests at their first consultations (besides the vaccines) in order to diagnose/discard as soon as possible any kind of disease that could complicate the little ones' lives in case nothing is done. 
Lucas de Oliveira Fernandes 1

(iD) https://orcid.org/0000-0003-0180-8215

Matheus Oliveira Silvano 2

iD https://orcid.org/0000-0002-4851-2203

Aline Baggio Oening 3

iD https://orcid.org/0000-0001-5903-0026

Chaiana Esmeraldino Mendes Marcon 4

iD https://orcid.org/0000-0001-7031-437X

1-4 Universidade do Sul de Santa Catarina. Av. José Acácio Moreira, 787. Dehon. Tubarão, SC, Brasil. CEP: 88.704-900. E-mail: chaianamarcon@gmail.com

\section{References}

1. Jaime PC, Frias PG, Monteiro HOC, Almeida PVB, Malta DC. Assistência em saúde e alimentação não saudável em crianças menores de dois anos: dados da Pesquisa Nacional de Saúde, Brasil, 2013. Rev Bras Saúde Mater Infant. 2016; 16 (2): $149-57$

2. Baranov A, Namazova-Baranova L, Albitskiy V, Ustinova N, Terletskaya R, Komarova O. The Russian Child Health Care System. J Pediatr. 2016; 177: S148 - S155.
3. González-Cossío T, Rivera-Dommarco J, Moreno-Macías H, Monterrubio E, Sepúlveda J, Poor Compliance with Appropriate Feeding Practices in Children under 2 y in Mexico. J Nutr. 2006; 136 (11): 2928-33.

Received on July 2, 2020

Approved on July 10, 2020 